\title{
Effects of Vigorous Blending on Yield and Quality of Protein Isolates Extracted From Cottonseed and Soy Flours
}

\author{
Zhongqi $\mathrm{He}^{1}$, Heping $\mathrm{Cao}^{1}$, Huai N. Cheng ${ }^{1}$, Haixuan Zou ${ }^{2} \&$ James F. Hunt ${ }^{3}$ \\ ${ }^{1}$ USDA Agricultural Research Service, Southern Regional Research Center, New Orleans, LA 70124, USA \\ ${ }^{2}$ Department of Chemical and Biological Engineering, the University of Maine, Orono, ME 04469, USA \\ ${ }^{3}$ USDA Agricultural Research Service, New England Plant, Soil and Water Laboratory, Orono, ME 04469, \\ USA
}

Correspondence: Zhongqi He, USDA-ARS, Southern Regional Research Center, 1100 Robert E. Lee Blvd., New Orleans, LA 70124, USA. Tel: 1-504-286-4516. E-mail: Zhongqi.He@ars.usda.gov

Received: August 27, 2013

Accepted: September 16, $2013 \quad$ Online Published: September 27, 2013

doi:10.5539/mas.v7n10p79

URL: http://dx.doi.org/10.5539/mas.v7n10p79

\begin{abstract}
Cottonseed protein has shown great potential as a biodegradable and renewable resource for industrial processes such as the manufacture of wood adhesives. To improve the recovery of the protein from cottonseed flour, we tested the effects of vigorous blending on the extraction efficiency and recovery yield of one- and two-step procedures for isolation of cottonseed protein. For comparison, the effects on one-step soy protein isolation were also examined. Our data indicated that vigorous blending improved the protein recovery from cottonseed and soy flour as much as $40-60 \%$, compared to mild agitation in the extraction phase. The improvement was likely due to the enhanced solid (flour)-liquid (extracting solvent) interaction, and the increased extraction temperature of the vigorous blending process. Similarities in the protein content, molecular mass distribution pattern, and secondary structure of each type of protein isolates processed under different blending treatments indicated that quality of the isolates was not altered by vigorous blending. However, dissimilarities in molecular mass distribution patterns and secondary structures were identified between the different types of isolates (i. e. total, water soluble, and alkali soluble cottonseed proteins, and total soy protein). These differences will enable us to explore in future work the correlations between cottonseed protein structures and industrial use characteristics (such as adhesive properties).
\end{abstract}

Keywords: cottonseed flour, soy flour, protein isolate, extraction, blending, FT-IR

\section{Introduction}

Cotton is one of the most important non-food crops in the world. From this interesting and renewable resource it is possible to obtain a large variety of products that can be utilized in many disparate fields (Proto et al., 2000). One possibility is the utilization of cottonseed (CS) proteins isolated after oil extraction, as a biodegradable and renewable source to make wood adhesives (Cheng et al., 2013; Lambuth, 2003). Cottonseed protein isolate (CSPI) is prepared from defatted cottonseed flour (CF) via alkaline extraction followed by acidic precipitation. This isolation technique utilizes the dissimilar solubilities of proteins in alkaline and acidic conditions to: (1) dissolve the protein from CF using alkaline solution, (2) get a clear alkaline protein supernatant by centrfugation, and (3) separate the CSPI fraction by adjusting the $\mathrm{pH}$ of the supernatant with acid until the protein's isoelectric point is attained (Berardi et al., 1969; Zhang et al., 2009). As the key point of this procedure is to recover as much CSPI from $\mathrm{CF}$ as possible, several controlling factors (i. e. solvent, $\mathrm{pH}$, temperature, medium, extraction time, and solvent/flour ratio) have been extensively investigated (Berardi et al., 1969; El Tinay et al., 1988; King \& Lamkin, 1977; Zhang et al., 2009). According to the literature, optimized extraction conditions with constant stirring resulted in approximately $50-70 \%$ protein isolation from CF. However, to our knowledge, the effect of vigorous agitation on the yield of cottonseed protein has not been tested even though the protein extraction involves a solid (flour)-liquid (extracting solution) mass transfer process. Previously, Fleming and Sosulski (1977) reported that wet grinding by a blending mixer raised the solubilty (yield) of sunflower protein, compared to a magnetic stirrer. Therefore, we hypothesized that vigorous blending would improve the extraction efficiency and recover more protein from CF than mild constant stirring, with all other extracting conditions left unchanged. Thus, we tested the hypothesis with both one-step and two-step extraction procedures for cottonseed protein 
isolation (Berardi et al., 1969). In addition, a different one-step preparation of soy protein isolate (SPI) (Huang \& Sun, 2000; Qi \& Sun, 2010) was also tested under similar blending conditions as SPI has been intestively investigated for indsutrial use.

\section{Materials and Methods}

\subsection{Materials}

Glanded CF came from an expander-solvent process and was produced under typical processing conditions except that the normal addition of hulls back to the kernels was reduced to increase the flour protein level (He et al., 2013). Soy meal was obtained from Kentwood Co-op (Kentwood, LA, USA). The soy flour (SF) sample was obtained by grinding the meal in a cyclone sample mill (Model 3010-014, UDY Cooporation, Fort Collins, CO, USA) to pass a 0.5 -mm steel screen. The protein content was $57.8 \%$ for cottonseed flour, and $49.6 \%$ for soy flour, respectively.

\subsection{One-Step Extraction of Cottonseed Protein Isolate}

This procedure was similar to that in the literature (Berardi et al., 1969), with the extraction time (stirring/blending time) as a treatment variable. Briefly, $13.0 \mathrm{~g}$ of CF was mixed with $195.0 \mathrm{~g}$ of $0.027 \mathrm{M} \mathrm{NaOH}$. The mixture was either stirred in a beaker by a magnet stirring bar for $30 \mathrm{~min}$ at room temperature $\left(22^{\circ} \mathrm{C}\right)$, or processed in a blender (Model WF2211214, Waring Commercial, Torrington, CT, USA) for 1, 2 or 3 cycles of low $(2 \mathrm{~min}) / \mathrm{high}(1 \mathrm{~min})$ speed blending modes. The interval time between blending cycles was 5-10 min. These mixtures were then transferd to 500-ml centrifuge bottle. The beaker or blender was rinsed three times with $0.027 \mathrm{M} \mathrm{NaOH}$ ( $5 \mathrm{~mL}$ each), and the rinsed solution was added into the corresponding centrifuge bottle. Those bottles were centrifuged for $20 \mathrm{~min}$ at $10{ }^{\circ} \mathrm{C}$ and $9,000 \mathrm{x}$ g. The protein laden supernatant was poured free from the insoluble debris. Acidification of the clear supernatant by $1 \mathrm{M} \mathrm{HCl}$ to $\mathrm{pH} 5.0$ produced protein precipitate. The acidified supernatant was placed aside for at least $30 \mathrm{~min}$ before centrifugation. The separated CSPI fractions were then freeze-dried.

\subsection{Two-Step Extraction of Cottonseed Protein Isolate}

The two-step procedure was used to separate water soluble and alkali soluble proteins (Berardi et al., 1969). Briefly, $13.0 \mathrm{~g}$ of CF was mixed with $195.0 \mathrm{~g}$ of distilled $\mathrm{H}_{2} \mathrm{O}$. The extraction conditions were the same as in the one-step procedure, except that the treatment of 1 cycle of vigorous blending was replaced with an additional 2 cycles of blending treatment. After centrifugation, the clear supernatants were acidified by $1 \mathrm{M} \mathrm{HCl}$ to $\mathrm{pH} 4.0$ to precipitate out the water soluble cottonseed proteins (CSPW). The residual parts of the water extraction were re-suspended in $195.0 \mathrm{~g}$ of $0.015 \mathrm{M} \mathrm{NaOH}$. Three suspensions with magnet bar stirring, with 2 and 3 cycles of vigorous blending, were then agitated by magnetic stirring bars for $30 \mathrm{~min}$. Another suspension with 2 cycles of blending in the water extraction was agitated by 1 cycle of the low $(2 \mathrm{~min}) /$ high $(1 \mathrm{~min})$ speed blending mode. The bottles with the agitated suspensions and rinsed solutions were centrifuged as described earlier. The alkali soluble cottonseed proteins (CSPA) were preciptated by acidifying the clear extracts to $\mathrm{pH} 7.0$ with $1 \mathrm{M} \mathrm{HCl}$, and separated by centrifugation. The separated protein isolates were then freeze-dried.

\subsection{One-Step Extraction of Soy Protein Isolate}

This procedure was based on that described in literature (Huang and Sun, 2000). Soy flour (13.0 g) was mixed with $195.0 \mathrm{~g}$ of distilled $\mathrm{H}_{2} \mathrm{O}$. The mixture was either stirred with a magnet bar for $30 \mathrm{~min}$ or vigorously blended as described in section 2.2. After the $\mathrm{pH}$ was adjusted to 8.5 using $1 \mathrm{M} \mathrm{NaOH}$, these mixtures were agitated for 20 additional min on magnetic stirrer plates. The clear extracts were obtained by centrifugation under the same conditions as for CSPI preparation, and their $\mathrm{pH}$ was adjusted to 4.2 with $1 \mathrm{M} \mathrm{HCl}$ to precipitate out SPI. These bottles were kept at $4{ }^{\circ} \mathrm{C}$ overnight, and then centrifuged to obtain the wet SPI fractions that were then freeze dried.

\subsection{Determination of Protein Concentrations and Molecular Mass Distribution}

Protein concentrations were determined by Bradford method using the Protein Assay Dye Reagent Concentrate (Bio-Rad, Hercules, CA) following treatment of the samples with $\mathrm{NaOH}$ as described previously (Cao, 2004). Briefly, protein samples were treated with $0.5 \mathrm{M} \mathrm{NaOH}$ (final concentration) with total volume of $60 \mathrm{uL}$ for 10 min at room temperature. Then $1 \mathrm{~mL}$ of the diluted dye reagent (1:5 in water) was added to each sample. Following incubation for $20 \mathrm{~min}$ at room temperature, the absorbance at $595 \mathrm{~nm}$ was measured using a SmartSpec3000 spectrophotometer (Bio-Rad). Bovine serum albumin (BSA) from Bio-Rad was used as the protein standard. Nitrogen content of freeze dried protein isolates was analyzed by combustion with a Leco TruSpec ${ }^{\circledR}$ instrument (St. Joseph, Michigan). The analyzer was calibrated with a corn gluten sample (11.5\% nitrogen), and standard operating procedures were used. Protein levels were calculated from the nitrogen values 
multiplied by a factor of 6.25 (Proto et al., 2000).

For SDS-polyacrylamide gel electrophoresis (PAGE), each protein isolate was dissolved in $0.027 \mathrm{M} \mathrm{NaOH}$ with a concentration of $10 \mathrm{mg} \mathrm{mL}^{-1}$. Based on the procedure in literature (Cao et al., 2012), these protein samples were denatured in SDS gel loading buffer at $90{ }^{\circ} \mathrm{C}$ for $10 \mathrm{~min}$. Protein mixtures were loaded onto $4-12 \%$ NuPAGE bis-tris gel (Invitrogen, Gaithersburg, MD) and separated by electrophoresis at $150 \mathrm{~V}$ for $75 \mathrm{~min}$. The protein gels were stained with Coomassie Brilliant Blue R-250 (Bio-Rad, 65 mg/L) in 45\% methanol with 10\% acetic acid overnight and destained in the same solution without the dye agent. Each lane was loaded with $20 \mu \mathrm{g}$ or $100 \mu \mathrm{g}$ of the extracted proteins.

\subsection{Fourier Transform Infrared Spectroscopy and Protein Secondary Structure Calculation}

Fourier transform-infrared (FT-IR) spectra of protein isolates were obtained from $\mathrm{KBr}$ discs. Each disc contained an approximately $1-\mathrm{mg}$ sample and $100 \mathrm{mg} \mathrm{KBr}$. The spectra were recorded in the 450 to $4000 \mathrm{~cm}^{-1}$ range on a Spectrum One FT-IR Spectrophotometer (PerkinElmer Instruments) (He \& Ohno, 2012). Each sample was scanned 24 times with a resolution of $2 \mathrm{~cm}^{-1}$. Secondary structural features of proteins were calculated from the amide I (1600-1700 $\left.\mathrm{cm}^{-1}\right)$ envelope by spectral deconvolution. For the deconvolution, a uniform gamma value of 2 and length $\%$ of 10 were used for all samples. Those gamma and length \% values were arrived at by trial and error, ie. using various combinations of different gamma/length\% values and finding that 2 and 10 usually gave spectra that showed good peak separation without excessive side peaks. We designated the $\alpha$-helix structure to $1,649-1,660 \mathrm{~cm}^{-1}$, the random coil structure to $1,638-1,648 \mathrm{~cm}^{-1}$, the $\beta$-sheet structure to $1,606-1,637 \mathrm{~cm}^{-1}$ and $1670-1680 \mathrm{~cm}^{-1}$, and $\beta$-turn structure to $1,660-1,700 \mathrm{~cm}^{-1}$ minus $1670-1680 \mathrm{~cm}^{-1}$ based on the literature (Zhang \& Hua, 2007; Zhao et al., 2008).

\section{Results and Discussion}

\subsection{Effects of Vigorous Blending on One-Step Extraction of Cottonseed Protein Isolate}

Under the mild agitation by a stirring bar, $51.4 \%$ of the protein in CF was extracted into $0.027 \mathrm{M} \mathrm{NaOH}$ (Table 1). In comparison to results obtained by the mild agitation, the vigorous blending led to CF protein extraction of $62.4,66.1$, and $67.1 \%$, respectively, for 1,2 , and 3 cycles of blending, which represented $20-30 \%$ more protein extracted (Table 1). When the protein in these extracts was precipitated by acidification, about $8 \%$ of CF protein remained in the residual solution. It is not surprising that the blending treatments in the early extraction step did not have any statistically significant $(P>0.05)$ impact on the protein precipitation. After freeze-drying, $57.1 \%$ to $79.8 \%$ of protein were recovered in the the final CSPI products. It should be noted that the final recoveries were indeed higher than the extraction yields. This difference was apparently due to the different assay methods used for solution and solid samples. Both sets of data showed the same pattern change of values with cycle repetition; $0<1<2<3$, which implied that the intrinsic assaying mechanisms, rather than experimetal error, led to the observed differences. For example, the different compostion of CSPI amino acids relative to those of the BSA protein standard used in the solution method (Figure 1) could have resulted in some degree of varying response to the Bradford assay dye reagent. The Coomassie Brilliant Blue G-250 dye primarily binds to basic and aromatic amino acid residues, especially arginine, so that differences in the polypeptides present in the solution and solid samples would strongly influence the results of the Bradford assay. Nevertheless, the recovery data confirmed the observation that vigorous blending had improved the extraction efficency.

In the experiment, the temperature of the extraction medium (solution) was changed from room temperature (22 ${ }^{\circ} \mathrm{C}$ ) to $33-34,43-44$ and $50-53{ }^{\circ} \mathrm{C}$, respectively, for 1, 2, and 3 cycles of blending. Berardi et al. (1969) observed little effect on protein extraction when the tempearature was changed from $25^{\circ} \mathrm{C}$ to $60{ }^{\circ} \mathrm{C}$. However, Zhang et al. (2009) reported that raising the temperature to $60{ }^{\circ} \mathrm{C}$ improved CS protein extraction. Thus, we hypothesized that the improvement in protein extraction observed following vigorous blending was due mainly to increases in the solid-solvent contact between flour particles and extractants; although increased solubility due to higher temperatures may have played some role as well. 
Table 1. Effects of vigorous blending on the cottonseed protein isolation

(A) One-step extraction procedure

\begin{tabular}{|c|c|c|c|}
\hline $\begin{array}{l}\text { Blending } \\
\text { cycle a }\end{array}$ & $\begin{array}{l}\text { Protein extracted into } \\
0.027 \mathrm{M} \mathrm{NaOH}\end{array}$ & $\begin{array}{l}\text { Protein left in the residual soluton } \\
\text { after } \mathrm{pH} 5.0 \text { preciptation }\end{array}$ & $\begin{array}{l}\text { Protein in freeze } \\
\text { dried isolate }\end{array}$ \\
\hline & \multicolumn{3}{|c|}{ 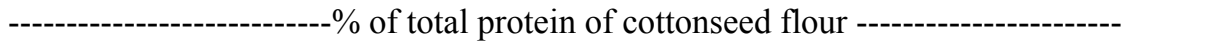 } \\
\hline 0 & $51.4 \pm 1.8 \mathrm{~b}$ & $8.5 \pm 4.0$ & $57.1 \pm 4.3$ \\
\hline 1 & $62.4 \pm 5.1^{*}$ & $8.7 \pm 4.2 \mathrm{~ns}$ & $75.4 \pm 1.4^{* *}$ \\
\hline 2 & $66.1 \pm 2.3 * * *$ & $8.0 \pm 3.6 \mathrm{~ns}$ & $78.4 \pm 2.9^{* *}$ \\
\hline 3 & $67.1 \pm 1.4 * * *$ & $7.5 \pm 2.7 \mathrm{~ns}$ & $79.8 \pm 1.2 * * *$ \\
\hline
\end{tabular}

(B) Two-step extraction procedure

\begin{tabular}{llll}
\hline $\begin{array}{l}\text { Blending } \\
\text { cycle c }\end{array}$ & $\begin{array}{l}\text { Protein extracted into } \\
\mathrm{H}_{2} \mathrm{O} \text { or } 0.015 \mathrm{M} \mathrm{NaOH}\end{array}$ & $\begin{array}{l}\text { Protein left in the residual soluton } \\
\text { after } \mathrm{pH} 4.0 \text { or } 7.0 \text { preciptation }\end{array}$ & $\begin{array}{l}\text { Protein in freeze } \\
\text { dried isolate }\end{array}$ \\
\hline & \multicolumn{2}{l}{ Water soluble protein $(\mathrm{CSPW})$} & \\
\cline { 2 - 3 } $0-0$ & $20.1 \pm 0.9$ & $6.2 \pm 0.8$ & $9.9 \pm 0.6$ \\
$2-0$ & $23.8 \pm 2.1^{*}$ & $4.8 \pm 0.8 \mathrm{~ns}$ & $15.5 \pm 1.0^{* * *}$ \\
$2-1$ & $23.1 \pm 0.4^{*}$ & $5.0 \pm 0.7 \mathrm{~ns}$ & $14.9 \pm 0.8^{* * *}$ \\
$3-0$ & $25.2 \pm 3.2^{*}$ & $3.7 \pm 0.6 \mathrm{~ns}$ & $15.8 \pm 0.5^{* * *}$ \\
\hline & Alkali soluble Protein (CSPA) & \\
$0-0$ & $57.6 \pm 0.5$ & $7.4 \pm 3.0$ & $55.4 \pm 0.9$ \\
$2-0$ & $56.6 \pm 0.3 \mathrm{~ns}$ & $7.1 \pm 4.4 \mathrm{~ns}$ & $58.6 \pm 1.5 \mathrm{~ns}$ \\
$2-1$ & $59.3 \pm 0.7^{*}$ & $5.8 \pm 2.7 \mathrm{~ns}$ & $57.2 \pm 0.3 \mathrm{~ns}$ \\
$3-0$ & $57.3 \pm 1.4 \mathrm{~ns}$ & $5.1 \pm 1.5 \mathrm{~ns}$ &
\end{tabular}

${ }^{a}$ Each cycle was 2-min low/1-min high speed blending. 0 cycle, control (i. e. flour was agitated by a magnetic stirring bar for 30 min without vigorous blending).

${ }^{\mathrm{b}}$ Average \pm standard deviation $(\mathrm{n}=3)$. Symbol $*, * *, * * *$ and $\mathrm{ns}$ in the same column of each protein fraction represent the significant difference between control and the blending treatments at $P=0.05,0.01,0.001$, and no significant difference at $P=0.05$, respectively.

${ }^{\mathrm{c}}$ Each cycle was 2-min low/1-min high speed blending for flour (first digit) or the resiudal parts of the water extraction (second digit). 0-0 cycle, control (i. e. flour and the residual parts of the water extraction were agitated by a magnetic stirring bar for $30 \mathrm{~min}$ without vigorous blending, respectively).

\subsection{Effects of Vigorous Blending on Two-Step Extraction of Cottonseed Protein Isolate}

The mild extractant water dissolved about $20 \%$ of the available protein, leading to approximately $10 \%$ of the protein isolated as the water soluble CSPW fraction (Table 1). In this water extraction phase, blending increased the extraction yield by $3-6 \%$ of total protein as shown by the protein contents in both the extracts and freeze-dried final samples. As in the one-step procedure, blending did not affect protein precipitation. More than half $(>50 \%)$ of the CS protein was in the alkali soluble CSPA fraction. In this alkali extraction step, an additional blending cycle (treament 2-1) increased protein extracted to $59.3 \%$ from $57.6 \%$ of control (0-0) significantly $(P=0.05)$. However, the observation was inconsitent with the final dried CSPA product with that yield was $58.1 \%$, but not statistically significant from $55.4 \%$ of the control $(0-0)(P=0.05)$ (Table 1). No statistically significant $(P=0.05)$ results of CSPA were observed between control $(0-0)$ and other two blending cycle treatments $(2-0$ and $3-0)$. Thus, we concluded that the effect of blending was mainly on improving the water soluble protein extraction. 


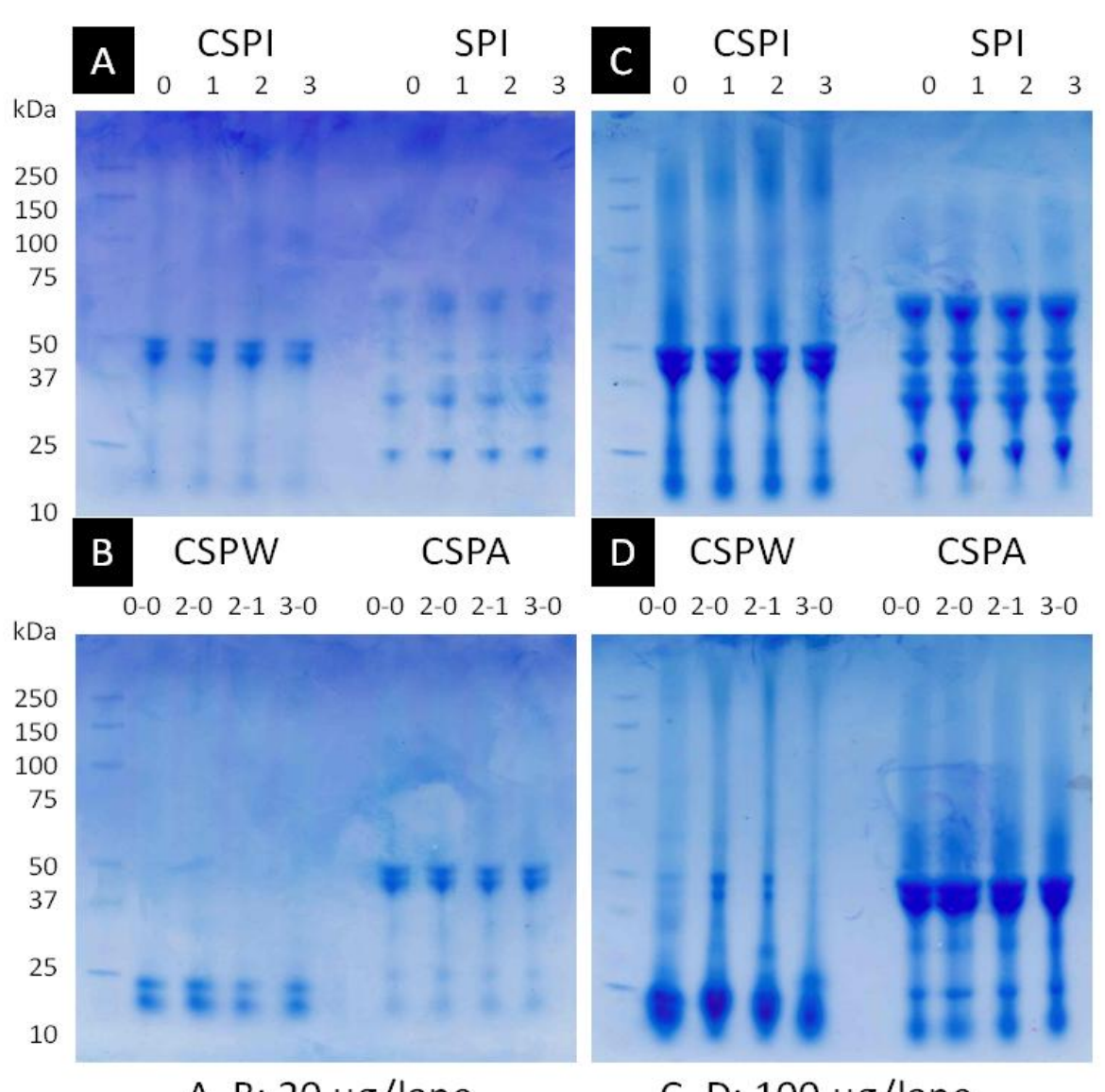

A, B: $20 \mu \mathrm{g} / \mathrm{lane}$

C, D: $100 \mu \mathrm{g} /$ lane

Figure 1. SDS-polyacrylamide gel electrophoresis of one-step prepared cottonseed (CSPI) and soy (SPI) protein isolates, two-step prepared water (CSPW) and alkali (CSPA) soluble cottonseed protein isolates. Each lane was loaded with $20 \mu \mathrm{g}$ (A and B) or $100 \mu \mathrm{g}$ (C and D) of the protein isolates. Refer to Table 1 for the blending cycle symbols

\subsection{Effects of Vigorous Blending on One-Step Extraction of Soy Protein Isolate}

The final recoveries of freeze dried SPI fractions were from $38 \%$ to $50 \%$ (Table 2), which was less than the recoveries of the one-step CSPI and the two-step CSPA fractions (Table 1). This was due to the less basic conditions ( $\mathrm{pH} 8.5$ ) used in the one-step SPI isolation compared with the $0.027 \mathrm{M}$ (about pH 10.5) and $0.015 \mathrm{M}$ $\mathrm{NaOH}$ (about pH 9.8) conditions used in the one- and two-step CSPI isolation. Despite these lower yields relative to cottonseed samples, the amount of soy protein recovered in both the extracted and freeze-dried isolates was $7-13 \%$ greater with vigorous blending during the extraction (Table 2). This observation further confirmed that vigorous blending could improve the extraction of oilseed proteins from their flours.

\subsection{Purity of Cottonseed and Soy Protein Isolates}

The purity (protein content in the freeze-dried isolates) was estimated by total $\mathrm{N}$ analysis and protein-dye coloric measurement (Table 3). As discussed in previous sections, the two sets of data are not exactly the same due to the different measuring mechanisms and interferences associated with each analysis, The purity of CSPA isolates measured by the two methods were quite similar, but those of the CSPW isolates were not. This observation implied that the difference in the two measurments was mainly due to the interference of water soluble ingredients. After examining all of the data, it is fair to say that about $90 \%$ or more of the dry mass in these isolates were proteins, and that there was no dramatic change in the protein content induced by vigorous blending. 
Table 2. Effects of vigorous blending on the soy protein isolation

\begin{tabular}{llcl}
\hline $\begin{array}{l}\text { Blending } \\
\text { cycle }^{\mathrm{a}}\end{array}$ & $\begin{array}{l}\text { Protein extracted } \\
\mathrm{H}_{2} \mathrm{O}(\mathrm{pH} 8.5)\end{array}$ & $\begin{array}{l}\text { into } \\
\text { Protein left in the residual soluton } \\
\text { after } \mathrm{pH} 4.2 \text { preciptation }\end{array}$ & $\begin{array}{l}\text { Protein in freeze dried } \\
\text { isolate }\end{array}$ \\
\hline & - & & \\
0 & $26.4 \pm 2.1^{\mathrm{b}}$ & $1.2 \pm 0.9$ & $37.9 \pm 2.4$ \\
1 & $33.9 \pm 4.2^{*}$ & $1.3 \pm 0.2 \mathrm{~ns}$ & $45.8 \pm 2.9^{*}$ \\
2 & $34.9 \pm 2.2^{* *}$ & $1.2 \pm 0.3 \mathrm{~ns}$ & $44.8 \pm 1.5^{*}$ \\
3 & $39.3 \pm 1.7^{* * *}$ & $1.2 \pm 0.1 \mathrm{~ns}$ & $49.7 \pm 1.6^{*}$
\end{tabular}

a $\overline{\text { Each cycle was } 2 \text {-min low/1-min high speed blending. } 0 \text { cycle, control (i. e. flour was agitated by a magnetic }}$ stirring bar for 30 min without vigorous blending).

${ }^{\mathrm{b}}$ Average \pm standard deviation $(\mathrm{n}=3)$. Symbol $*, * *, * * *$ and $\mathrm{ns}$ in the same column represent the significant difference between control and the blending treatments at $P=0.05,0.01,0.001$, and no significant difference at $P=0.05$, respectively.

\subsection{Polypeptide Composition of Cottonseed and Soy Protein Isolates}

SDS-PAGE was used to examine the polypeptide composition of these protein isolates (Figure 1). The gels with both 20 and $100 \mathrm{~g}$ protein load lane ${ }^{-1}$ showed similar results but the gels with less loading of the total proteins resulted in better resolution of the major $50 \mathrm{kDa}$ and $20 \mathrm{kDa}$ protein bands into two polypeptides in CSPI, CSPW, and CSPA isolates (Figure 1A and 1B). It can be clearly seen that the CSPI fraction (Figure 1A) consisted of low molecular mass CSPW (approximately $20 \mathrm{kDa}$ ) and high molecular mass CSPA (approximately $50 \mathrm{kDa}$ ) (Figure 1B). The relevent intensities of the two bands in the CSPI lanes (Figure 1A) were consistent with the yields of CSPW and CSPA extracted in the two-step procedure (Table 1). The major molecular bands were observed in the same isolate extracted with different blending cycles, indicating the minor impact of blending on the molecular distribution of these isolates. The low and high molecular masses of the CSPW and CSPA were reported in Berardi et al. (1969). Furthermore, the molecular mass distribution of CSPW isolate was similar to Band IV and $\mathrm{V}(22-14 \mathrm{kDa})$ of cottonseed storage globuline, and the major bands of CSPA isolate were in the range of Band I and II (53 and $46 \mathrm{kDa})$ with a minor Band III $(37-32 \mathrm{kDa})$ (King, 1980). The differences in the banding patterns between this study and previous report (King, 1980) were probably due to the uses of different SDS-PAGE system. Amino acid analysis revealed uneven distribution of three major storage amino acids (glutamate, arginine and aspartate) among the proteins represented by these bands, as being 5-6 times higher in Band III and IV than in Band I, II, and V (King, 1980).

The molecular mass distribution of SPI was quite different from that of CSPI as a major band with $65 \mathrm{kDa}$ appeared only in the SDS-PAGE of SPI and more polypeptides were observed in SPI (Figure 1A vs. 1C). Although several molecular mass bands were observed in both isolates, the intenstities of these bands were in a complementary mode. For example, the band at $50 \mathrm{kDa}$ was strong in CSPI, but weak in SPI. On the other hand, bands at 35 and $25 \mathrm{kDa}$ were strong in SPI, but weak in CSPI. It was not clear if these differences were due to the different $\mathrm{pHs}$ used in protein extraction and/or precipitation, or to the intrinsic differences in composition of the two types of proteins, although a similar molecular mass distribution pattern of SPI was reported previously (Zhao et al., 2008). Anyway, the different molecular mass patterns of these four protein isolates may provide us with an opportunity to test if any adhesive properties of these protein isolates are relevant to the molecular mass. 
Table 3. Purity and secondary structures of cottonseed and soy protein isolates

\begin{tabular}{|c|c|c|c|c|c|c|}
\hline \multirow{2}{*}{$\begin{array}{l}\text { Blending } \\
\text { cycle }^{\mathrm{a}}\end{array}$} & \multicolumn{2}{|c|}{ Purity ( $\%$ of dry matter) ${ }^{b}$} & \multicolumn{4}{|c|}{ Secondary structures ( $\%$ of total structure) } \\
\hline & $\mathrm{N}$ analysis & Color & $\alpha$-Helix & $\beta$-Sheet & $\beta$-Turn & Random coil \\
\hline \multicolumn{7}{|l|}{ CSPI } \\
\hline 0 & $97.6^{\mathrm{c}}$ & 76.7 & 13.1 & 42.3 & 32.7 & 11.9 \\
\hline 1 & $95.5 \mathrm{~ns}$ & $80.8 \mathrm{~ns}$ & $13.8^{*}$ & $40.4 *$ & $33.7 *$ & $12.1 \mathrm{~ns}$ \\
\hline 2 & $94.4 \mathrm{~ns}$ & $86.2 \mathrm{~ns}$ & $13.4 \mathrm{~ns}$ & $41.6 \mathrm{~ns}$ & $33.2 \mathrm{~ns}$ & $11.8 \mathrm{~ns}$ \\
\hline 3 & $93.6^{*}$ & $78.4 \mathrm{~ns}$ & $13.3 \mathrm{~ns}$ & $42.2 \mathrm{~ns}$ & $32.8 \mathrm{~ns}$ & $11.8 \mathrm{~ns}$ \\
\hline Average $^{\mathrm{d}}$ & 95.3 & 78.0 & 13.4 & 41.4 & 33.2 & 11.9 \\
\hline$\pm \mathrm{SD}$ & $\pm 1.7 \mathrm{~A}$ & $\pm 2.1 \mathrm{~A}$ & $\pm 0.3 \mathrm{~A}$ & $\pm 0.9 \mathrm{~A}$ & $\pm 0.5 \mathrm{~A}$ & $\pm 0.2 \mathrm{~A}$ \\
\hline \multicolumn{7}{|l|}{ CSPW } \\
\hline $0-0$ & 89.8 & 98.9 & 14.3 & 40.3 & 33.1 & 12.3 \\
\hline $2-0$ & $86.2 * * *$ & $99.1 \mathrm{~ns}$ & $14.3 \mathrm{~ns}$ & $40.1 \mathrm{~ns}$ & $33.5^{*}$ & $12.1 \mathrm{~ns}$ \\
\hline $2-1$ & $85.7 * * *$ & $96.8 \mathrm{~ns}$ & $14.5 \mathrm{~ns}$ & $39.7 \mathrm{~ns}$ & $33.7^{*}$ & $12.1 \mathrm{~ns}$ \\
\hline $3-0$ & $82.5^{* * *}$ & $90.0 \mathrm{~ns}$ & $14.0 \mathrm{~ns}$ & $40.8 \mathrm{~ns}$ & $33.4 \mathrm{~ns}$ & $11.8 \mathrm{~ns}$ \\
\hline Average & 85.8 & 96.2 & 14.3 & 40.2 & 33.5 & 12.0 \\
\hline$\pm \mathrm{SD}$ & $\pm 3.1 \mathrm{~B}$ & $\pm 4.3 \mathrm{~B}$ & $\pm 0.2 \mathrm{~B}$ & $\pm 0.5 \mathrm{~B}$ & $\pm 0.2 \mathrm{~A}$ & $\pm 0.2 \mathrm{~A}$ \\
\hline \multicolumn{7}{|l|}{ CSPA } \\
\hline $0-0$ & 108.7 & 92.4 & 13.7 & 40.8 & 33.3 & 12.2 \\
\hline $2-0$ & $110.0 \mathrm{~ns}$ & $103.7 \mathrm{~ns}$ & $13.6 \mathrm{~ns}$ & $40.8 \mathrm{~ns}$ & $33.4 \mathrm{~ns}$ & $12.2 \mathrm{~ns}$ \\
\hline $2-1$ & $106.4 \mathrm{~ns}$ & $113.6 \mathrm{~ns}$ & $13.5 \mathrm{~ns}$ & $41.6^{*}$ & $32.9 \mathrm{~ns}$ & $12.1 \mathrm{~ns}$ \\
\hline $3-0$ & $109.6 \mathrm{~ns}$ & $106.6 \mathrm{~ns}$ & $13.5 \mathrm{~ns}$ & $41.1 \mathrm{~ns}$ & $33.2 \mathrm{~ns}$ & $12.1 \mathrm{~ns}$ \\
\hline Average & 108.6 & 104.0 & 13.5 & 41.2 & 33.2 & 12.1 \\
\hline$\pm \mathrm{SD}$ & $\pm 1.5 \mathrm{C}$ & $\pm 8.8 \mathrm{~B}$ & $\pm 0.1 \mathrm{~A}$ & $\pm 0.4 \mathrm{~A}$ & $\pm 0.2 \mathrm{~A}$ & $\pm 0.1 \mathrm{~A}$ \\
\hline \multicolumn{7}{|l|}{ SPI } \\
\hline 0 & 92.4 & 74.9 & 13.4 & 41.7 & 33.0 & 11.9 \\
\hline 1 & $90.2 * * *$ & $84.5 \mathrm{~ns}$ & $13.9^{*}$ & $39.9 *$ & $34.0^{*}$ & $12.2 *$ \\
\hline 2 & $89.6^{* *}$ & $80.6 \mathrm{~ns}$ & $13.0^{*}$ & $42.5^{*}$ & $32.6^{*}$ & $11.9 \mathrm{~ns}$ \\
\hline 3 & $89.8^{* *}$ & $80.7 \mathrm{~ns}$ & $13.3 \mathrm{~ns}$ & $41.7 \mathrm{~ns}$ & $33.1 \mathrm{~ns}$ & $12.0 \mathrm{~ns}$ \\
\hline Average & 90.5 & 80.2 & 13.4 & 41.4 & 33.2 & 12.0 \\
\hline$\pm \mathrm{SD}$ & $\pm 1.3 \mathrm{D}$ & $\pm 3.9 \mathrm{~A}$ & $\pm 0.4 \mathrm{~A}$ & $\pm 1.3 \mathrm{AB}$ & $\pm 0.7 \mathrm{~A}$ & $\pm 0.2 \mathrm{~A}$ \\
\hline
\end{tabular}

${ }^{a}$ CSPI and SPI are cottonseed and soy protein isolates from one-step procedures. CSPW and CSPA are water and alkali soluble cottonseed protein isolates from the two-step procedure. Refer to Table 1 for the blending cycle symbles.

${ }^{\mathrm{b}}$ Protein purity was compared based on two methods (i.e. total $\mathrm{N}$ analysis and protein coloric measurement).

${ }^{c}$ Values were calculated from triplicate measurements. Symbol $*, * *, * * *$ and ns in the same column of a protein isolate represent the significant difference between control $(0-0)$ and the blending treatments at $P=0.05,0.01$, 0.001 , and no significant difference at $P=0.05$, respectively.

${ }^{\mathrm{d}}$ Average \pm standard deviation of the four blending treatments. Values with a same uppercase letter in the same column of all protein isolates are not statistically significant $(P=0.05)$ between the protein isolates

\subsection{Secondary Structures of Cottonseed and Soy Protein Isolates}

The repesentative FT-IR spectra of protein isolates are shown in Figure 2. Even though no FT-IR spectra of cottonseed protein have been reported before, the major spectral features of CSPI and SPI were quite similar to 
each other, and to those of soy proteins (i. e. 7S and 11S globulins) in the literature (Chen et al., 2013). The peaks at 1653,1532 and $1236 \mathrm{~cm}^{-1}$ were attributed to amide I ( $\mathrm{C}=\mathrm{O}$ stretching), II (CN stretching, $\mathrm{NH}$ bending), and III (CN stretching, NH bending) bands of proteins, respectively (Kong \& Yu, 2007; Chen et al., 2013). The minor peak at $1309 \mathrm{~cm}^{-1}$ also belonged to the amide III band. This minor peak was observd in the spectrum of alkali soluble CSPA, but was not obvious in that of water soluble CSPW, indicting some structural difference between the two fractions of cottonseed protein. In contrast, a small peak at $1173 \mathrm{~cm}^{-1}$ and a shoulder band at $926 \mathrm{~cm}^{-1}$ were observed in the spectrum of CSPW. We attribute those two bands to phytate compounds (He et al., 2006). This assignment is supported by elemental analysis in the literature (Berardi et al., 1969) which showed 7 times higher phosphorus in CSPW than in CSPA of the two-step precedure. The intensties of the three bands at 1309,1173 , and $926 \mathrm{~cm}^{-1}$ in the spectrum of CSPI were between those of CSPW and CSPA, indicating that both protein fractions sequentially extracted in the two-step procedure were also present in the one-step extracted CSPI. However, the separated CSPW and CSPA fractions obtained from the two step-procedure would provide us the opprotunity to explore and compare physico-chemical properties and potential of different applications of the water- and alkaline- protein fractions.

The protein secondary structures calculated from FT-IR amide I bands are listed in Table 3 . The relative distribution of the secondary structures in all protein samples were $\beta$-sheet $(\sim 40 \%)>\beta$-turn $(\sim 33 \%)>\alpha$-helix $(\sim 14 \%)>$ random coil $(\sim 12 \%)$. The distribution pattern is similar to those of secondary structures of soy $7 \mathrm{~S}$ and $11 \mathrm{~S}$ proteins in the literature (Zhang \& Hua, 2007; Zhao et al., 2008). Even though chemcial modification (Zhang \& Hua, 2007) and extracting solvent (Zhao et al., 2008) could alter the secondary structures, data in Table 3 indicated that the mechanical force of vigorous blending did not exert much effects on these protein secondary structures. Similar to the qualitative visual observation of FT-IR spectra, differences in the secondary structures between CSPW and other protein isolates was observed, reflected in higher $\alpha$-helix and lower $\beta$-sheet contents of CSPW. Although the differences were within $1 \%$, they were statistically significant $(P=0.05)$. As the secondary structure is one of protein factores affecting protein-based adhesive properties (Huang \& Sun, 2000; Zhang \& Hua, 2007), it is of interest to explore in the future which of the two water and alkali soluble fractions of cottonseed protein could be a better wood adhesive. The similarity of the secondary structures of one-step prepared CSPI and SPI implies that these two types of protein may have similar adhesive properties. In other words, the knowledge of the properties of SPI adhesives could be applicable to CSPI-based products, thus benifitting and facilitating the development of CSPI-based wood adhesives.

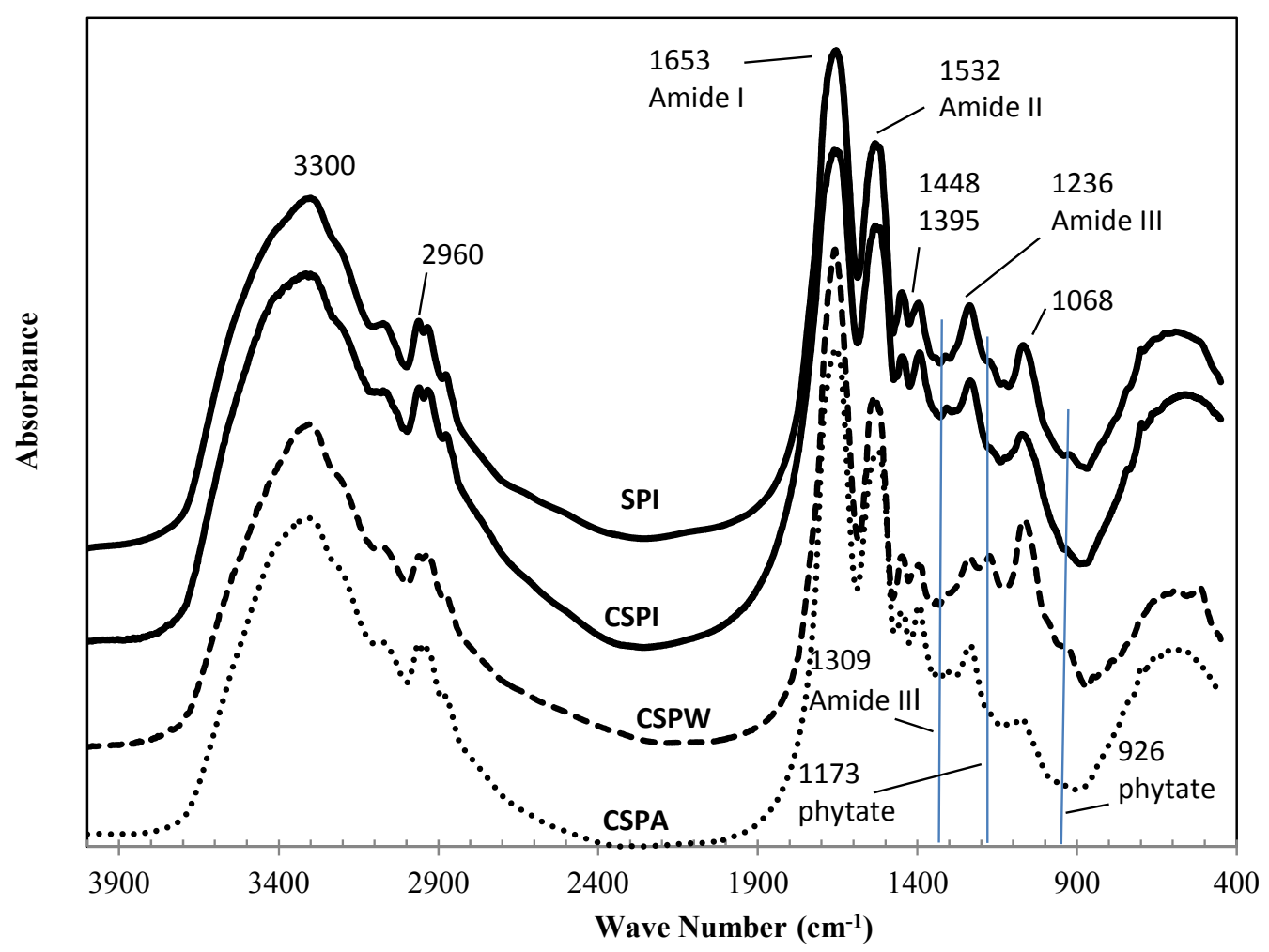

Figure 2. FT-IR spectra of one-step prepared cottonseed (CSPI) and soy (SPI) protein isolates, two-step prepared water (CSPW) and alkali (CSPA) soluble cottonseed protein isolates under mild stirring extraction conditions 


\section{Conclusions}

As demonstrated by one-step procedures for CSPI and SPI isolation, vigorous blending during extraction improved the extraction efficiency and final recovery of proteins by $20-40 \%$, compared to the same procedures with mild agitation during extraction. Data derived from two-step isolation of cottonseed proteins showed that the beneficial effect of vigorous blending was on the first extraction of CSPW (up to $60 \%$ more isolate than control) with less effect on the second isolation phase for CSPA fractions.

Protein analysis, SDS-polyacrylamide gel electrophoresis and FT-IR spectroscopy of these protein isolates indicated no significant differences in purity, molecular mass distribution pattern or secondary structure in the same type of protein isolates obtained with different blending treatments, suggesting no quality changes of these isolates by the blending. However, some differences in molecular mass distribution and/or the secondary structure were found between CSPI, CSPW, CSPA, and/or SPI. Exploring the correlation between these differences and adhesive properties of these protein isolates may shed new light on the development of improved plant protein based wood adhesives.

\section{Acknowledgments}

We thank Dorselyn Chapital, Scott Pelitire, and Kim Daigle for technical assistance during this work. Mention of trade names or commercial products in this publication is solely for the purpose of providing specific information and does not imply recommendation or endorsement by the U.S. Department of Agriculture. USDA is an equal opportunity provider and employer.

\section{References}

Berardi, L. C., Martinez, W. H., \& Fernandez, C. J. (1969). Cottonseed protein isolates: Two step extraction procedure. Food Technol., 23, 75-82.

Cao, H. (2004). Expression, purification, and biochemical characterization of the antiinflammatory tristetraprolin: a zinc-dependent mRNA binding protein affected by posttranslational modifications. Biochem., 43, 13724-13738. http://dx.doi.org/10.1021/bi049014y

Cao, H., Chapital, D. C., Howard, O. D., Deterding, J. L., Mason, C. B., Shockey, J. M., \& Klasson, T. K. (2012). Expression and purification of recombinant tung tree diacylglycerol acyltransferase 2. Appl. Microbiol. Biotechnol., 96, 711-727. http://dx.doi.org/10.1007/s00253-012-3869-7

Chen, J., Chen, X., Zhu, Q., Chen, F., Zhao, X., \& Ao, Q. (2013). Determination of the domain structure of the $7 \mathrm{~S}$ and 11S globulins from soy proteins by XRD and FTIR. J. Sci. Food Agric., 93, 1687-1691. http://dx.doi.org/10.1002/jsfa.5950

Cheng, H. N., Dowd, M. K., \& He, Z. (2013). Investigation of modified cottonseed protein adhesives for wood composites. Ind. Crop. Prod., 46, 399-403. http://dx.doi.org/10.1016/j.indcrop.2013.02.021

El Tinay, A. H., Nour, A. M., Abdel-Karim, S. H., \& Mahgoub, S. O. (1988). Aqueous protein and gossypol extraction from glanded cottonseed flour: factors affecting protein extraction. Food Chem., 29, 57-63. http://dx.doi.org/10.1016/0308-8146(88)90076-3

Fleming, S. E., \& Sosulski, F. W. (1977). The utilization of sunflower protein in milk-like beverages. Can Inst. Food Sci. Tech. J., 10, 229-233. http://dx.doi.org/10.1016/S0315-5463(77)73539-4

He, Z., Honeycutt, C. W., Zhang, T., \& Bertsch, P. M. (2006). Preparation and FT-IR characterization of metal phytate compounds. J. Environ. Qual., 35, 1319-1328. http://dx.doi.org/10.2134/jeq2006.0008

He, Z., \& Ohno, T. (2012). Fourier transform infrared and fluorescence spectral features of organic matter in conventional and organic dairy manure. J. Environ. Qual., 41, 911-919. http://dx.doi.org/10.2134/jeq2011.0226

He, Z., Cheng, H. N., Chapital, D. C., \& Dowd, M. K. (2013). Sequential fractionation of cottonseed meal to improve its wood adhesive properties. J. Am. Oil Chem. Soc. in press. http://dx.doi.org/10.1007/s11746-013-2349-2

Huang, W., \& Sun, X. S. (2000). Adhesive properties of soy proteins modified by urea and guanidine hydrochloride. J. Am. Oil Chem. Soc., 77, 101-104. http://dx.doi.org/10.1007/s11746-000-0016-6

King, E. E. (1980). Compositional relationships among electrophoretic isolates from cottonseed protein bodies. Phytochem., 19, 1647-1651. http://dx.doi.org/10.1016/S0031-9422(00)83786-3

King, E. E., \& Lamkin, G. E. (1977). Isolation of proteins from glanded cottonseed. J. Agric. Food Chem., 25, 
1211-1213. http://dx.doi.org/10.1021/jf60213a039

Kong, J., \& Yu, S. (2007). Fourier transform infrared spectroscopic analysis of protein secondary structures. Acta Biochim. Biophys. Sin., 39, 549-559. http://dx.doi.org/10.1111/j.1745-7270.2007.00320.x

Lambuth, A. L. (2003). Protein adhesives for wood., In: Pizzi, A., \& Mittal, K. L. (Eds.). Handbook of Adhesive Technology. Marcel Dekker, Inc., New York, N.Y., pp. 457-478. http://dx.doi.org/10.1201/9780203912225.ch20

Proto, M., Supino, S., \& Malandrino, O. (2000). Cotton: a flow cycle to exploit. Ind. Crop. Prod., 11, 173-178. http://dx.doi.org/10.1016/S0926-6690(99)00060-6

Qi, G., \& Sun, X. S. (2010). Peel adhesion properties of modified soy protein adhesive on a glass panel. Ind. Crop. Prod., 32, 208-212. http://dx.doi.org/10.1016/j.indcrop.2010.04.006

Zhang, B., Cui, Y., Yin, G., Li, X., \& Zhou, X. (2009). Alkaline extraction method of cottonseed protein isolate. Modern Appl. Sci., 3(3), 77-82.

Zhang, Z., \& Hua, Y. (2007). Urea-modified soy globulin proteins (7S and 11S): Effect of wettability and secondary structure on adhesion. J. Am. Oil Chem. Soc., 84, 854-857. http://dx.doi.org/10.1007/s11746-007-1108-7

Zhao, X., Chen, F., Xue, W., \& Lee, L. (2008). FTIR spectra studies on the secondary structures of 7S and 11S globulins from soybean proteins using AOT reverse micellar extraction. Food Hydrocoll., 22, 568-575. http://dx.doi.org/10.1016/j.foodhyd.2007.01.019

\section{Copyrights}

Copyright for this article is retained by the author(s), with first publication rights granted to the journal.

This is an open-access article distributed under the terms and conditions of the Creative Commons Attribution license (http://creativecommons.org/licenses/by/3.0/). 